foundation stock, for it took 13 generations of selection before the polymorphism began to develop ${ }^{1,3}$.

The evidence put forward also seems to demonstrate that recombination was involved in the establishment of this polymorphism as has already been suggested ${ }^{3}$ and as Mather's ${ }^{5}$ genetic models would imply.

At the same time the population provides a nice example of a situation in which a recessive lethal can be produced by recombinational instead of mutational change.

J. B. GrBson

J. M. THODAY

Department of Genetics,

University of Sheffield,

1 Thoday, J. M., Nature, 181, 1124 (1958)

Thoday, J. M., Heredity, 13, 187 (1959)

8 Thoday, J. M., and Boam, T. B., Heredity, 13, 205 (1959).

- Mather, K., Evolution, 9, 52 (1955).

5 Mather, K., Biol, Rers., 18, 32 (1913)

\section{Cytological Identification of Proliferating Donor Cells in Chick Embryos injected with Adult Chicken Blood}

THE enlargement of the embryonic chick spleen which accompanies chorio-allantoic grafting of adult chicken spleen was first described by Murphy ${ }^{1}$ in 1916. This phenomenon attracted the attention of a number of workers who believed that the splenomegaly was brought about by a proliferation of embryonic cells in response to some stimulus provided by the implanted spleen $^{2,3}$. Simonsen ${ }^{4}$ in 1957 showed that the splenic enlargement also occurred following the intravenous injection into the embryo of adult chicken blood or spleen cells. He showed that most embryos injected with homologous adult blood died of hæmolytic anæmia and the results of Coombs' tests strongly suggested that antibodies against the host red blood cells were present. He carne to the conclusion from the results of his experiments that proliferating donor cells were responsible for the antibody production and the splenic enlargement.

It is generally agreed that the fifth largest chromosome is paired in the male domestic chicken and single in the female $e^{5,6}$ and this is supported by our own observations on embryonic gonads and spleens. We have used this difference to identify male cells in the spleens of female chick embryos inoculated with cockerel blood. We have thus been able to provide a direct demonstration of the presence of cells of donor origin in the embryos.

Chick embryos of 14 days' incubation were inoculated intravenously with $0.1 \mathrm{ml}$. of citrated cockerel blood and were killed four days later. In the later experiments the colchicine-like action of demecolcine was used to increase the number of mitotic figures and to assist spreading of the chromosomes. This drug was given by injection into the allantoic cavity three hours before killing the embryos. The most satisfactory dose of demecolcine was $0.05 \mathrm{mgm}$. per embryo. The enlarged spleens from the female embryos were chopped up with scissors and the frag. ments incubated in half-strength Hanks' saline or 1.12 per cent trisodium citrate solution for 20 minutes at $37^{\circ} \mathrm{C}$. The splenic fragments were handled as a suspension in centrifuge tubes and stained with Feulgen's reagent. The stained tissues were then examined by the squash technique?. No attempt was made to count the total number of chromosomes in the cells studied since identification of the sex of the cells depends upon the recognition of the paired or single

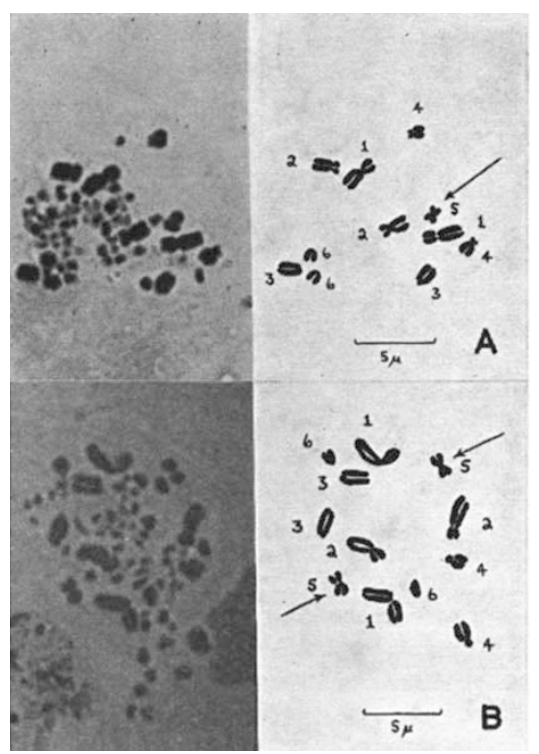

Fig. 1. Photographs with drawings of two cells in metaphase from the spleen of an 18-day-old female embryo inoculated at 14 days old with cockerel blood. The six largest pairs of chromosomes only are shown in each drawing. $A$, Female cell with single fifth chromosome; $B$, male cell with paired fifth chromosome

state of the fifth metacentric chromosome. Cells in which the 5 or 6 largest pairs of chromosomes could be identified were considered to be intact, and those with a paired fifth chromosome were identified as male cells, and those with a single fifth chromosome as females.

Male cells were found in all 15 female embryo spleens examined. A total of 170 metaphases derived from the 9 female embryos treated with demecolcine were sexed, and 75 identified as male cells and 95 as female cells. Fig. 1 shows male and female cells in metaphase. The relative proportions of metaphases of each sex varied with the embryos. No cells with paired fifth chromosomes were seen in a total of 70 metaphases from the spleens of 4 control female embryos.

These results provide a direct confirmation of the presence of cells derived from the injected blood in the embryo spleens. The relatively high proportion of female metaphases in the female spleens suggests however that an appreciable component of the splenic enlargement is provided by embryo cells.

The technique of using the sex chromosome as a cell marker has considerable potentialities in working with avian tissue, and should be of value for the cytological identification of chimerism in the domestic chicken in experiments on acquired tolerance.

We are indebted to C.I.B.A. Laboratories Ltd., for supplying the demecolcine ('Colcemid').

P. M. BIGGS

L. N. PAYNe

Department of Veterinary Medicine, University of Bristol, Langford House, Langford, Nr. Bristol.

1 Murphy, J. G., J. Exp. Med., 24, 1 (1916).

2 Danchakoft, V., Amer. J. Anat., 20, 255 (1916).

3 Ebert, J. D., Physiol. Zool., 24, 20 (1951).

- Simonsen, M., Acta Path. Microviol. Scand., 40, 480 (1957),

5 Newcomer, E. H., J. Hered., 48, 227 (1957)

Van Brink, J. M., and Ubbels, G. A., Experientia, 12, 162 (1956).

2 Ford, C. E., and Hamerton, J. L., Stain'Tech., 31, 247 (1956). 